\section{IMMUNE INFILTRATES DIFFERENCES BETWEEN CENTRAL AND PERIPHERY REGIONS OF COLORECTAL AND PANCREAS ADENOCARCINOMAS}

${ }^{1}$ Andreia Maia*, 'Joana Lérias, ${ }^{2}$ Luis Miguel Borrego, ${ }^{3}$ Markus Maeurer, ${ }^{3}$ Mireia CastilloMartin. 'Champalimaud Centre for the Unknown, Lisbon, Portugal; ${ }^{2}$ CEDOC, Chronic Diseases Research Center, Lisbon, Portugal; ${ }^{3}$ Champalimaud Foundation, Lisbon, Portugal

Background The tumor microenvironment (TME) is a complex system, where malignant cells co-exist and communicate with immune and non-immune cells. ${ }^{1}$ This interaction orchestrates an immune response that regulates and recruits other immune cells that may either promote cancer growth or mediate tumor regression. ${ }^{2}$ The number and spatiotemporal distribution of tumor-infiltrating lymphocytes (TILs) in the TME, as well as NK cells, have been correlated with favorable prognosis in patients with colorectal cancer or pancreatic adenocarcinomas (CRC and PDAC). ${ }^{3-5} \mathrm{~A}$ more detailed analysis of the TME landscape composition will help to understand which specific areas will give rise to immune cells with clinically relevant anti-cancer-directed responses and could be preferentially expanded for immunotherapy using tumor-infiltrating NK cells.

Methods Fresh CRC $(\mathrm{n}=6)$ and PDAC $(\mathrm{n}=6)$ tumor specimens were obtained within 20 minutes after surgery. A certified GI pathologist collected central and periphery tumor regions. From each region, half of the specimen was used for immunophenotypic analysis, the other half was cultured with IL-2 $(1000 \mathrm{IU} / \mathrm{mL})$ for 12 days. Immunophenotyping was performed using CD45, CD19, CD3, CD4, CD8, CD56, CD16, and LiveDead marker by flow cytometry at days 0,6 , and 12. Parallel formalin-fixed paraffin-embedded blocks were generated and analyzed by immunohistochemistry (IHC) for CD8 and CD56.

Results The immuneprofile of the tumor center and periphery is different both in CRC and PDAC. The mean percentages of B-cells, T-cells $\left(\mathrm{CD}^{+}\right.$and $\mathrm{CD}^{+}{ }^{+} \mathrm{T}$-cells $)$ and $\mathrm{NK}$ cells $\left(\mathrm{CD} 56^{\text {bright }} \mathrm{CD} 16^{-}\right.$and $\mathrm{CD} 56^{+} \mathrm{CD} 16^{+}$) of tumor regions are presented in figure 1) are more abundant in the TME and formed larger clusters than NK cells (figure 2). The majority of NK cells were found in the stroma however, in some cases, NK cells were located within the malignant epithelium.

\section{Abstract 933 Table 1}

\begin{tabular}{|c|c|c|c|c|c|c|c|c|c|}
\hline \multicolumn{2}{|c|}{ Tumor } & Mean \% & $\begin{array}{l}\mathrm{CD}^{+} 9^{-} \\
\text {B-cells }\end{array}$ & $\begin{array}{c}\mathrm{CD3}^{+} \\
\text {T-cells }\end{array}$ & $\underset{\text { T-cells }}{\mathrm{CD} L^{+}}$ & $\begin{array}{c}\text { CD8* } \\
\text { T-cells }\end{array}$ & NK cells & $\begin{array}{c}\text { CD56 bright } \\
\text { CD16- }\end{array}$ & $\begin{array}{l}\text { CD56 } \\
\text { CD16 }\end{array}$ \\
\hline \multirow{6}{*}{ CRC } & \multirow{3}{*}{ Central } & Day 0 & 6.0 & 68.4 & 35.0 & 27.2 & 9.6 & 33.3 & 31.7 \\
\hline & & Day 6 & 4.5 & 84.5 & 42.8 & 31.6 & 5.0 & 41.5 & 22.9 \\
\hline & & Day 12 & 0.7 & 87.3 & 46.3 & 32.3 & 8.8 & 67.8 & 20.9 \\
\hline & \multirow{3}{*}{ Peripheric } & \begin{tabular}{|l|} 
Day 0 \\
\end{tabular} & 9.5 & 73.5 & 33.9 & 31.5 & 4.5 & 27.7 & 38.8 \\
\hline & & Day 6 & 6.2 & 75.2 & 33.4 & 24.6 & 6.9 & 41.7 & 20.7 \\
\hline & & \begin{tabular}{|l|} 
Day 12 \\
\end{tabular} & 2.1 & 84.9 & 48.8 & 25.0 & 6.9 & 65.6 & 10.3 \\
\hline \multirow{6}{*}{ PDAC } & \multirow{3}{*}{ Central } & Day 0 & 15.4 & 65.8 & 30.5 & 31.3 & 9.4 & 6.1 & 54.9 \\
\hline & & Day 6 & 5.3 & 84.3 & 47.7 & 29.1 & 3.8 & 28.0 & 30.1 \\
\hline & & Day 12 & 0.5 & 91.1 & 52.4 & 31.9 & 5.4 & 55.7 & 17.6 \\
\hline & \multirow{3}{*}{ Peripheric } & Day 0 & 12.6 & 75.4 & 37.2 & 34.5 & 2.7 & 11.1 & 54.2 \\
\hline & & Day 6 & 4.5 & 88.3 & 48.5 & 34.0 & 2.7 & 35.6 & 22.1 \\
\hline & & Day 12 & 1.8 & 87.0 & 50.2 & 29.3 & 6.8 & 49.6 & 12.9 \\
\hline
\end{tabular}

Representation of percentage of immune cells in the central and periphery tumor regions of both CRC and PDAC tissues. The mean percentage of B-cells, T-cells (including $\mathrm{CD}^{+}$and $\mathrm{CD} 8^{+}$-T-cells) and NK cells (including CD56 ${ }^{\text {bright }} \mathrm{CD}^{-} 6^{-}$and $\mathrm{CD} 6^{+} \mathrm{CD} 16^{+}$subpopulation) during ex vivo expansion (day 0 , day 6 and day 12) are represented from the different regions of both CRC $(n=6)$ and PDA $(n=6)$.

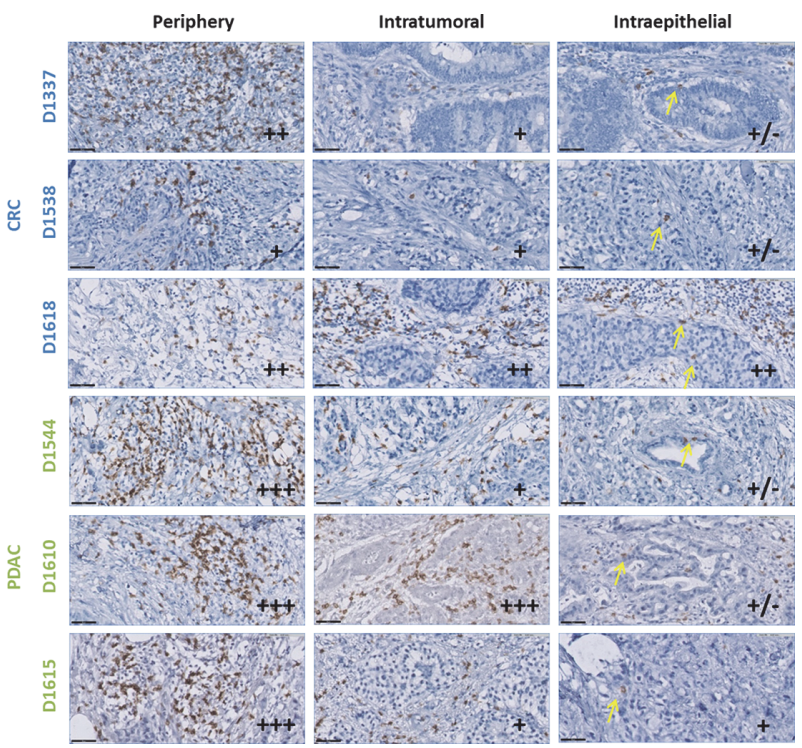

Abstract 933 Figure 1 Representative IHC images of CD8 ${ }^{+}$- T-cells in different regions: stroma (periphery and intratumoral) and intraepithelial of both CRC $(n=3)$ and PDAC ( $n=3)$. Semi-quantitative analysis of $C D 8^{+}$. T-cells (from negative $(-)$ to high numbers $(+++)$ ). Yellow arrows point to intraepithelial CD8 ${ }^{+}$- T-cells. Scale bar corresponds to $50 \mu \mathrm{m}$.

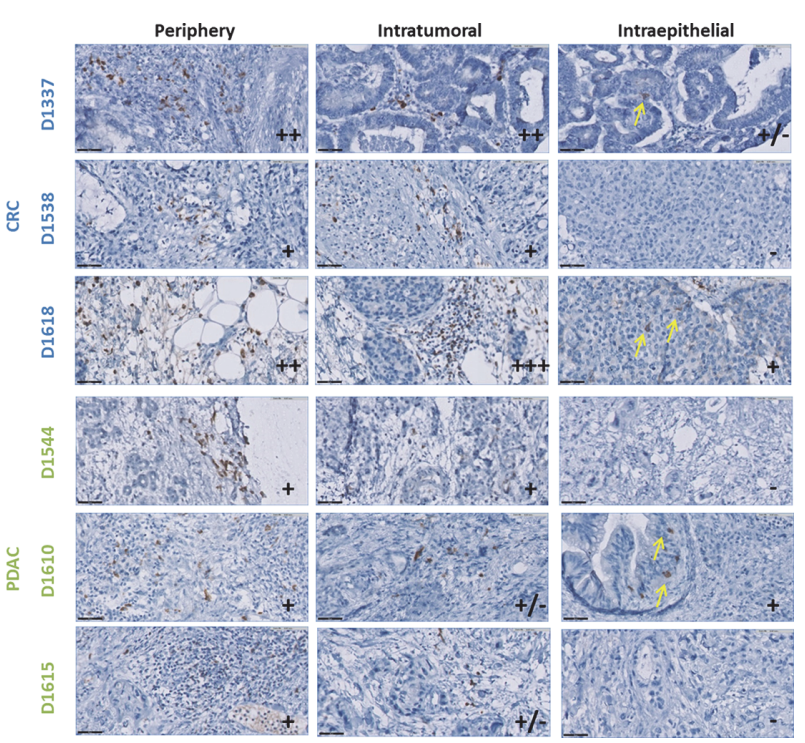

Abstract 933 Figure 2 Representative IHC images of $\mathrm{CD}^{2} 6^{+} \mathrm{NK}$ cells in different regions: stroma (periphery and intratumoral) and intraepithelial of both CRC $(n=3)$ and PDAC $(n=3)$. Semi-quantitative analysis of $\mathrm{CD}^{+} 6^{+}$NK cells (from negative $(-)$to high numbers $(+++)$). Yellow arrows point to intraepithelial $\mathrm{CD}_{56}{ }^{+} \mathrm{NK}$ cells. Scale bar corresponds to $50 \mu \mathrm{m}$.

Conclusions Our data in this small set of specimens show that TME immune cells in central and periphery tumor regions present different phenotypes in both tumor types. The tumor periphery exhibits a stronger infiltration with TIL and NK 
cells as compared to the center. We also observed that immune cells are in close physical contact with tumor cells since they were identified inside the malignant epithelium in some specimens. NK-cells and particularly TIL close to cancer cells may be preferentially harvested to obtain improved anticancer-directed NK or TCR alpha-beta-directed immune cell products for active immunotherapy.

Acknowledgements The authors would like to thank the Champalimaud Foundation Biobank of the Champalimaud Centre for the Unknown for anonymously releasing tissue specimens.

\section{Trial Registration N/A}

\section{REFERENCES}

1. Giraldo NA, Sanchez-Salas R, Peske JD, Vano Y, Becht E, Petitprez F, Validire P, Ingels $A$, Cathelineau $X$, Fridman $W H$, et al. The clinical role of the TME in solid cancer. Br J Cancer (2019);120:45-53.

2. Li L, Yu R, Cai T, Chen Z, Lan M, Zou T, Wang B, Wang Q, Zhao Y, Cai Y. Effects of immune cells and cytokines on inflammation and immunosuppression in the tumor microenvironment. Int Immunopharmacol (2020);88:106939.

3. Lianyuan $T$, Dianrong $X$, Chunhui $Y$, Zhaolai M, Bin J. The predictive value and role of stromal tumor-infiltrating lymphocytes in pancreatic ductal adenocarcinoma (PDAC). Cancer Biol Ther (2018);19:296-305.

4. Idos GE, Kwok J, Bonthala N, Kysh L, Gruber SB, Qu C. The prognostic implications of tumor-infiltrating lymphocytes in colorectal cancer: a systematic review and meta-analysis. Sci Rep (2020);10:3360.

5. Zhang S, Liu W, Hu B, Wang P, Lv X, Chen S, Shao Z. Prognostic significance of tumor-infiltrating natural killer cells in solid tumors: a systematic review and meta-analysis. Front Immunol (2020);11:1-11.

Ethics Approval This study was approved by the Champalimaud Foundation Ethics Committee and by the Ethics Research Committee of NOVA Medical School of NOVA University of Lisbon; approval number 56.

Consent Written informed consent was obtained from the patient for publication of this abstract and any accompanying images. A copy of the written consent is available for review by the Editor of this journal.

http://dx.doi.org/10.1136/jitc-2021-SITC2021.933 